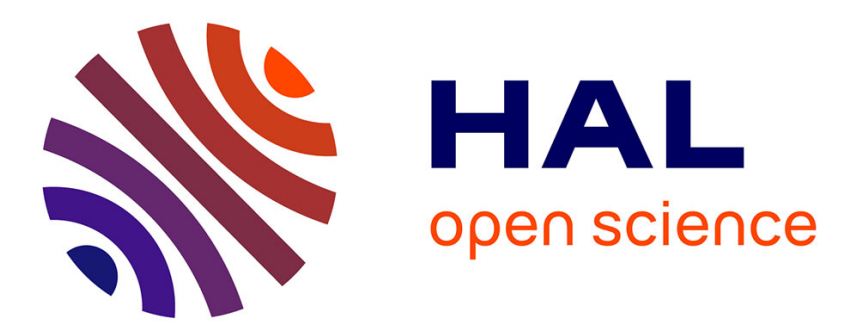

\title{
Could the use of saliva substitutes improve food oral processing in individuals with xerostomia? A systematic review
}

Sophie Piaton, Anne Duconseille, Valérie Roger-leroi, Martine Hennequin

\section{- To cite this version:}

Sophie Piaton, Anne Duconseille, Valérie Roger-leroi, Martine Hennequin. Could the use of saliva substitutes improve food oral processing in individuals with xerostomia? A systematic review. Journal of Texture Studies, 2021, 52 (3), pp.278-293. 10.1111/jtxs.12591 . hal-03285510

\author{
HAL Id: hal-03285510 \\ https://hal.uca.fr/hal-03285510
}

Submitted on 13 Jul 2021

HAL is a multi-disciplinary open access archive for the deposit and dissemination of scientific research documents, whether they are published or not. The documents may come from teaching and research institutions in France or abroad, or from public or private research centers.
L'archive ouverte pluridisciplinaire HAL, est destinée au dépôt et à la diffusion de documents scientifiques de niveau recherche, publiés ou non, émanant des établissements d'enseignement et de recherche français ou étrangers, des laboratoires publics ou privés.

\section{(c)(1)}

Distributed under a Creative Commons Attribution| 4.0 International License 
Could the use of saliva substitutes improve food oral processing in individuals with xerostomia? A systematic review

\section{Short title : Saliva substitutes and FOP}

Sophie Piaton ${ }^{1,2}$, Anne Duconseille ${ }^{1}$, Valérie Roger-Leroi ${ }^{1,2}$, Martine Hennequin ${ }^{1,2}$

${ }^{1}$ Université Clermont Auvergne, CROC, F-63000 Clermont-Ferrand, France.

${ }^{2}$ CHU de Clermont-Ferrand, Service d'Odontologie, F-63003 Clermont-Ferrand, France

\section{Corresponding author}

$$
\text { Prof Martine Hennequin }
$$

CROC EA4847 UFR d'Odontologie

2 rue de Braga

63000 Clermont-Ferrand

France

Email: martine.hennequin@uca.fr

Tel: 0033473177381 


\section{ABSTRACT}

$\mid 24$

Xersotomia seeks to document whether products called "saliva substitutes” or "artificial saliva” can really replace saliva in food oral processing. Pubmed and Science Direct were searched for articles using the keywords "saliva substitutes” and "artificial saliva”. An advanced search was applied using the terms "xerostomia" and/or "food oral processing" and/or "eating” and/or “mastication” and/or “chewing” and/or "swallowing”. The analysis methods and the inclusion criteria were documented in a protocol published in the International prospective register of systematic reviews (PROSPERO with the registration number CRD42019124585).

The search included 43 articles, published between 1979 and 2017. Among the included studies, 17 were observational studies, 5 were pilot studies, 21 were crossover studies and 14 of these studies were blinded. The Strobe score for the included articles varied from 7.5 to 20 .

The possible effects of the use of saliva substitutes on the ingestion function were poorly investigated. No evidence was based on physiological studies. It is unknown whether using a saliva substitute has an effect on the composition and rheological properties of the food bolus, on the lubrication of the oral and laryngeal mucosa or on both phenomena. Moreover, saliva substitutes were not formulated to improve food oral processing and most of them are flavoured. New saliva substitutes and artificial saliva should be designed and formulated to improve food oral processing. 2

Keywords: Xerostomia, Sjögren’s syndrome, saliva substitutes, artificial saliva, Food oral Processing, review 


\section{INTRODUCTION}

Xerostomia is a subjective feeling of dryness in the mouth related to possible quantitative and qualitative changes in saliva composition (Fox, Busch, \& Baum, 1987). It should be differenciated from hyposalivation which results from an objective assessment of a reduced salivary flow rate (Łysik, Niemirowicz-Laskowska, Bucki, Tokajuk, \& Mystkowska, 2019). The causes of xerostomia are heterogenous, and may or may not be related to saliva production deficiencies. Among the origins of xerostomia, one can distinguish the consequences of salivary diseases (salivary gland trauma ${ }_{2}$-and-tumor, surgery or radiotherapies), from the effects of systemic chronic diseases (Ehronic, autoimmmene, diabete mellitus, Sjogren’s syndrome, lupus erythematosus and others autoimmune disorders), dehydration, mouth breathing or the adverse effects of drugs. More than 400 medicines are associated with xerostomia (Porter, Scully, \& Hegarty, 2004). Determining the epidemiology of xerostomia is complex due to the unclear definitions of dry mouth being used and the different methods for measuring this condition (Ying Joanna \& Thomson, 2015). A systematic review reported that the prevalence of xerostomia ranged from $8 \%$ to $42 \%$, while the prevalence of hyposyalia varied from $12 \%$ to $47 \%$ (Hopcraft \& Tan, 2010). Xerostomia prevalence is estimated to be approximately $20 \%$ in the general population, with an increased prevalence in women (up to 30\%) and in elderlies (up to 50\%) (Furness, Worthington, Bryan, Birchenough, \& McMillan, 2011). Overall, 54\% of people complaining of xerostomia actually had objective evidence of hyposalivation after salivary flow measurements were taken (Longman et al., 1997).

Various treatments were proposed to patients with xerostomia. Saliva stimulants and saliva substitutes aim to alleviate the symptoms of xerostomia. Saliva stimulants activate the salivary gland function. Their composition is based either on pilocarpine, a nonselective muscarinic agonist, or on cemivaline, which has specific affinity for receptor subtypes. The indications of saliva stimulants are restricted to individuals suffering from hyposalivation. Saliva substitutes 
have no effect on saliva production. They are indicated for all patients suffering from xerostomia, including those having hyposalivation. Artificial saliva products definitely are not saliva. They were developed to imitate and act as saliva but they do not act as saliva for all of its complex functions (antimicrobial, digestive/perceptive, teeth protection etc.. )._are indicated for all patients suffering for xerostomia, including those having hyposalivation.

The effects of saliva substitutes have been reported in many studies measuring self-perception of pain, comfort in mouth and quality of life related to oral health. However, it is not clear whether saliva substitutes could improve eating capacities and the nutritional status. The question is challenging, as saliva plays vital roles in maintaining oral health and in food oral processing (FOP). Food oral processing covers all ingestive functions and includes sucking, biting, chewing, manipulating the food with the tongue and swallowing. The dryness of the mouth affects both the oral preparatory and oral phases of swallowing, and can lead to impaired bolus formation and oropharyngeal bolus transport. This can cause chewing and swallowing difficulty and may influence the quality and/or quantity of dietary intakes.

Previous research showed that a reduced salivary flow rate and/or subjective oral dryness were associated with food avoidance and low nutritional assessment. It was shown that the use of a mucin-containing saliva substitute three times a day before meals treats xerostomia and oral mucosa disorder in elderlies (Blixt-Johansen, Sjöholm, Wiesel, \& Ek, 1992). Moreover, meals duration was longer after the treatment period than before. The consequences of xerostomia on swallowing depend on the food type. For friable and non hydrophilic foods, the collection of particles into a single bolus could be affected, as could its transportation towards the pharynx (Liedberg, Ekberg, \& Owall, 1991). Indeed, there is little information about the association between hyposalivation and actual nutrient intake (Iwasaki et al., 2016). A systematic review and meta-analysis identified a clear gap in knowledge on the influence of saliva incorporation and oral lubrication on appetite ratings and food intake (Krop et al., 2018). The influence of the 
lubrication parameters of food on appetite and food intake remains largely unquantified. This review seeks to document whether the products called "saliva substitutes" or "artificial saliva" can really replace saliva during food oral processing.

\section{MATERIALS AND METHODS}

A systematic review was conducted based on the Preferred Reporting Items for Systematic reviews and Meta-analyses Protocol (PRISMA-P) statement (Moher et al., 2015). The analysis methods and inclusion criteria were documented in a protocol published in the International prospective register of sytematic reviews (PROSPERO with the registration number CRD42019124585).

\subsection{Search}

The search was designed to find articles reporting the use of saliva substitutes in individuals with xerostomia, in order to answer the question: Could the use of saliva subsitutes improve food oral processing?

\subsection{Information sources}

Pubmed and Science Direct were searched for articles using the keywords "saliva substitutes" and "artificial saliva". An advanced search was applied using the terms "xerostomia” and/or “food oral processing” and/or “eating” and/or “mastication” and/or “chewing” and/or “swallowing”. The PRISMA protocol was applied for article selection reviews (Moher et al., 2015). Criteria for exclusion were: articles not written in English, animal studies, in vitro studies, articles with off-topics and reviewed articles. The remaining records were assessed for screening and abstracts were read. Any article reporting an evaluation of saliva substitute was included in the eligibility phase. The remaining records were assessed for eligibility and full texts were read. The Strobe Grade approach (Cuschieri, 2019) was use to grade the quality of the evidence in the different studies. Three systematic reviews aimed at evaluating the efficacy 
of interventions for management of dry mouth were excluded (Furness, Bryan, McMillan, Birchenough, \& Worthington, 2013; Furness et al., 2011; Hahnel, Behr, Handel, \& Bürgers, 2009).

\subsection{Data extraction}

A Microsoft Excel ${ }^{\circledR}$ chart file was created and a pre-piloted form was tested for 10 articles by two investigators. Any quantitative or qualitative variable was considered as one item and noted as a column label while the articles included were listed in the arrows. Depending on the articles, some items were either not described or not available. Finally, twenty eight items were listed for data extraction: design trial; population description (number of subjects, number of females, number of males, age, number of groups of individuals, number of treatment per groups, aetiology of xerostomia, exclusion criteria, salivary flow); treatment (saliva substitute name, form, composition, posology); study parameters (duration, measurement frequency, control group, placebo, primary outcomes, secondary outcomes); objective and/or subjective measurements; significant results for primary and secondary outcomes; subjects’ preferences for using a substitute; study grade. A last column was added to check whether saliva substitutes had an effect on one or more FOP functions such as biting, chewing, manipulating food between tongue, palate, teeth and cheek and /or swallowing.

\subsection{Strategy for data synthesis}

Qualitative results were written as a narrative review. The term "saliva substitute" was used to refer to both "saliva substitute” and "artificial saliva”. 


\section{RESULTS}

\subsection{Search results}

The flow chart for inclusions is presented in Figure 1. The search included 43 articles, published between 1979 and 2017 (Aliko, Alushi, Tafaj, \& Isufi, 2012; Alpöz et al., 2015, 2008; Alves, Motta, Messina, \& Migliari, 2004; Andersson et al., 1995; Apperley, Medlicott, Rich, Hanning, \& Huckabee, 2017; Blixt-Johansen et al., 1992; Bots et al., 2005; Dalodom et al., 2016; Davies \& Singer, 1994; Dirix, Nuyts, Vander Poorten, Delaere, \& Van den Bogaert, 2007; Donath, Tonner, Chavda, Gatignol, \& Bouyrie, 2016; Duxbury, Thakker, \& Wastell, 1989; Epstein, Emerton, Le, \& Stevenson-Moore, 1999; Epstein \& Stevenson-Moore, 1992; Frost, Shirlaw, Walter, \& Challacombe, 2002; Furumoto, Barker, Carter-Hanson, \& Barker, 1998; GilMontoya, Subirá, Ramón, \& González-Moles, 2008; Heydarirad, Rezaeizadeh, Choopani, Mosavat, \& Ameri, 2017; Jellema et al., 2001; Johansson, Andersson, Attström, Glantz, \& Larsson, 1994; Klestov et al., 1981; Matear \& Barbaro, 2005; McMillan, Tsang, Wong, \& Kam, 2006; Momm, Volegova-Neher, Schulte-Mönting, \& Guttenberger, 2005; Morales-Bozo et al., 2017; Mouly, Orler, et al., 2007; Mouly, Salom, et al., 2007; Nakamoto, 1979; Oh, Lee, Kim, \& Kho, 2008; Regelink, Vissink, Reintsema, \& Nauta, 1998; Rogus-Pulia, Gangnon, Kind, Connor, \& Asthana, 2018; Salom et al., 2015; Shahdad, Taylor, Barclay, Steen, \& Preshaw, 2005; Silvestre, Minguez, \& Suñe-Negre, 2009; Skrinjar et al., 2015; Stewart et al., 1998; Sweeney, Bagg, Baxter, \& Aitchison, 1997; Temmel, Quint, Schickinger-Fischer, \& Hummel, 2005; van der Reijden, van der Kwaak, Vissink, Veerman, \& Amerongen, 1996; Visch, Gravenmade, Schaub, Van Putten, \& Vissink, 1986; Vissink et al., 1983)

Among the included studies, 17 were observational studies, 5 were pilot studies, 21 were crossover studies and 14 of these studies were blinded. The Strobe score for the included articles varied from 7.5 to 20. Xerostomia aetiologies and methods used to assess Food Oral Processing in included studies are reported in Table 1. 


\subsection{Review}

There are few objective and direct evaluations of the impact of the use of saliva substitutes on Food Oral Processing. Overall, 30 studies used visual analogue scales and /or Likert scales to evaluate the self-perception of subjects for the level of dryness of their mouth or throat, swallowing, chewing and speaking difficulties, level of thirst, taste disturbance, or denture retention (Aliko et al., 2012; Alpöz et al., 2015, 2008; Dalodom et al., 2016; Davies, Daniels, Pugh, \& Sharma, 1998; Davies \& Singer, 1994; Dirix et al., 2007; Donath et al., 2016; Epstein et al., 1999; Frost et al., 2002; Johansson et al., 1994; Matear \& Barbaro, 2005; Nakamoto, 1979; Regelink et al., 1998; Temmel et al., 2005; Visch et al., 1986; Vissink, Burlage, Spijkervet, Veerman, \& Nieuw Amerongen, 2004). Four studies asked subjects to report on the improvement in dryness related to the use of saliva substitutes (Salom et al., 2015; Silvestre et al., 2009; Stewart et al., 1998; van der Reijden et al., 1996). Six studies reported the impact of xerostomia on Quality of life (GOHAI (McMillan et al., 2006), OHIP 14 (Gil-Montoya et al., 2008; Skrinjar et al., 2015), EORTC - QLQ + H\&35 (Heydarirad et al., 2017; Jellema et al., 2001), QoL (Dirix et al., 2007)). In one observation report, the staff of an establishement for elderlies measured meal duration, reported the residents' pain complaints and subjectively assessed their ability to speak, eat and swallow (Blixt-Johansen et al., 1992). Sixteen studies globally measured the impact of xerostomia using validated (Apperley et al., 2017; Bots et al., 2005; McMillan et al., 2006; Morales-Bozo et al., 2017), or non validated (Alves et al., 2004; Andersson et al., 1995; Frost et al., 2002; Furumoto et al., 1998; Gil-Montoya et al., 2008; Klestov et al., 1981; Momm et al., 2005; Mouly, Orler, et al., 2007; Mouly, Salom, et al., 2007; Oh et al., 2008; Shahdad et al., 2005; Sweeney et al., 1997) comprehensive questionnaires.

Xerostomia was described in different conditions of gender, age and medical condition. The age range was from 18 to 94 and gender was not a criterion for inclusion. The medical conditions observed were: radiotherapy and/or chemotherapy after head and neck cancers 
(Andersson et al., 1995; Apperley et al., 2017; Dirix et al., 2007; Epstein \& Stevenson-Moore, 1992; Epstein et al, 1999; Jellema et al., 2001; Momm \& Guttenberger, 2002; Nakamoto, 1979; Regelink et al., 1998; Shahdad et al., 2005), systemic auto immune disease (Aliko et al., 2012; Alpöz et al., 2008; Alves et al., 2004; Klestov et al., 1981; van der Reijden et al., 1996); drug consumption (Donath et al., 2016; Mouly, Orler, et al., 2007; Skrinjar et al., 2015); elderlies (Mouly, Salom, et al., 2007; Rogus-Pulia et al., 2018); final stage renal disease on haemodialysis (Bots et al., 2005). Regardless of the aetiology of xerostomia, controlling the effect of saliva substitutes on the production of a swallowable food bolus is of importance.

The possible effects of saliva substitutes on FOP were reported in 1413_articles for swallowing only (Blixt-Johansen et al., 1992; Davies et al., 1998; Davies \& Singer, 1994; Dirix et al., 2007; Donath et al., 2016; Epstein et al., 1999; Jellema et al., 2001; Klestov et al., 1981; Matear \& Barbaro, 2005; Morales-Bozo et al., 2017; Nakamoto, 1979; Rogus-Pulia et al., 2018; van der Reijden et al., 1996) and in one article for mastication with objective measurements (Apperley et al., 2017). Evaluation of difficulties/easiness to swallow, to chew, to eat and/or to sip liquids were reported in 22 studies. Positive effects on FOP based on statistical analysis were assessed in 14 studies (Aliko et al., 2012; Alpöz et al., 2008; Alves et al., 2004; Andersson et al., 1995; Frost et al., 2002; Heydarirad et al., 2017; McMillan et al., 2006; Momm et al., 2005; MoralesBozo et al., 2017; Mouly, Orler, et al., 2007; Mouly, Salom, et al., 2007; Rogus-Pulia et al., 2018; Salom et al., 2015; Shahdad et al., 2005). Only one clinical trial measured xerostomia with a validated questionnaire and compared the effects of three different saliva substitutes on the chewing kinematics during ingestion of crackers (Apperley et al., 2017). The Test of Of Mastication and-And Swallowing Solids (TOMASS) required ingestion of a cracker as quickly and as comfortably as possible (Hägglund, Blom, Thoden, \& Karlsson, 2020; Huckabee et al., 2018). During mastication, the number of cycles, chewing time, and swallows per bite were measured. It was found that the use of saliva substitutes slightly improved xerostomia but had 
no effect on chewing kinematic parameters during the cracker eating. The authors suggested that TOMASS test was not appropriate to evaluate mastication in subjects with xerostomia.

\section{DISCUSSION}

This review demonstrated showed that the possible effects of the use of saliva substitutes on the ingestion function were poorly investigated. No evidence is-was based on physiological studies. Saliva participates in food bolus constitution, affects its rheological properties and initiates digestion. Food bolus rheology has a dominant influence on mastication and swallowing (Chen, 2007). During FOP, saliva gradually fills the gap between food particles and increases their viscous cohesion. The swallowing threshold is defined as the moment when the food bolus reaches the maximum cohesive force (Prinz \& Lucas, 1997). It is unknown whether the use of a saliva substitute has an effect on the composition and the rheological properties of the food bolus, on the lubrication of the oral and laryngeal mucosa or on both these phenomena. Moreover, it is clear that saliva substitutes are not developed to improve FOP. For example, most of the saliva substitute listed in Table 1 have mint, grapefruit, lemon or sweet flavouring. A flavoured saliva substitute could affect the perception of food and could limit the use of the saliva substitute during meals. Spontaneous food consumption could be altered for individuals using a saliva substitute, independently of the consequences of xerostomia.

Natural saliva is a non-Newtonian fluid. This characteristic ensures bolus aggregation and the lubrication of the oral and laryngeal mucosa during FOP. It could be suggested that a saliva substitute should be a non-Newtonian fluid. However, among the saliva substitutes used within the 14 studies reporting a possible positive effect of saliva substitutes on FOP, seven were based on mucine and/or xanthan gum and could be considered as natural saliva simulators (NSS), six were Newtonian fluids based on carboxymethyl cellulose or glycerol and two were 
uncategorized (Table 12 ). In most cases, non-Newtonian saliva substitutes contain substances of natural origin (salivary macromolecules such as mucins, lysozyme, lactoferrin) that provide high biocompatibility. However, mucines have pig or cow origins, which can affect the uses of the corresponding saliva substitute in some individuals for cultural reasons. The challenges of treating xerostomia are to mimic all properties of natural saliva definitely in order to improve oral comfort between and during meals.

The selection criteria of this review excluded the "saliva stimulant" keyword. Saliva stimulants are parasympathomimetics such as Pilocarpine or Cevimeline. These substances are indicated to improve the production of saliva compared with a placebo (LeVeque et al., 1993). The use of chewing gum was also described to increase saliva production. However, chewing a gum can be indicated only for persons whose salivary glands respond to stimulation. Saliva stimulant cannot meet the needs of all patients with xerostomia, contrary to saliva substitutes. It can be difficult to determine the amount of saliva that is indicative of the dysfunction of the salivary glands. The measurement of the salivary flow is the basis for the diagnosis of xerostomia/hyposalivation. Among the included studies, 28 reported a measure of saliva flow (Aliko et al., 2012; Alpöz et al., 2015, 2008; Andersson et al., 1995; Bots et al., 2005; Dalodom et al., 2016; Donath et al., 2016; Duxbury et al., 1989; Epstein et al., 1999; Epstein \& StevensonMoore, 1992; Frost et al., 2002; Furumoto et al., 1998; McMillan et al., 2006; Morales-Bozo et al., 2017; Mouly, Orler, et al., 2007; Mouly, Salom, et al., 2007; Oh et al., 2008; Regelink et al., 1998; Silvestre et al., 2009; Skrinjar et al., 2015; Stewart et al., 1998; Sweeney et al., 1997; van der Reijden et al., 1996). Overall, hyposalivation was observed when salivary flow rate at rest falls below $0.1 \mathrm{~mL}$ per minute and stimulated saliva (Sreebny, 2000) below $0.5-0.7 \mathrm{~mL}$ per minute; (Navazesh, Christensen, \& Brightman, 1992; Ship, DeCarli, Friedland, \& Baum, 1990). However, the sialometric techniques used to measure the salivary flow varied a lot, the spitting method being the most often reported. Moreover, the salivary flow rate threshold as an 
inclusion/exclusion criterion was set at different levels in different studies. Overall, the saliva flow was measured in 22 studies, while only seven studies considered the value of the saliva flow as an inclusion criterion (Table Z3).

To conclude, this review underscores the need to develop new saliva substitutes to improve the rheological properties of the bolus and the lubrication of the laryngeal mucosa. Flavours should be excluded from their composition.

\section{ETHICAL STATEMENT}

Declarations of interest: The authors declare that they do not have any conflict of interest

\section{REFERENCES}

Aliko, A., Alushi, A., Tafaj, A., \& Isufi, R. (2012). Evaluation of the clinical efficacy of Biotène Oral Balance in patients with secondary Sjögren's syndrome: A pilot study. Rheumatology International, 32(9), 2877-2881. https://doi.org/10.1007/s00296-0112085-6

Alpöz, E., Çankaya, H., Güneri, P., Epstein, J. B., Boyacioglu, H., Kabasakal, Y., \& Ocakci, P. T. (2015). Impact of Buccotherm ${ }^{\circledR}$ on xerostomia: A single blind study. Special Care in Dentistry, 35(1), 1-7. https://doi.org/10.1111/scd.12074

Alpöz, E., Güneri, P., Onder, G., Cankaya, H., Kabasakal, Y., \& Köse, T. (2008). The efficacy of Xialine in patients with Sjögren's syndrome: A single-blind, cross-over study. Clinical Oral Investigations, 12(2), 165-172. https://doi.org/10.1007/s00784-0070159-3 
Alves, M. B., Motta, A. C. F., Messina, W. C., \& Migliari, D. A. (2004). Saliva substitute in xerostomic patients with primary Sjögren's syndrome: A single-blind trial. Quintessence International (Berlin, Germany: 1985), 35(5), 392-396.

Andersson, G., Johansson, G., Attström, R., Edwardsson, S., Glantz, P. O., \& Larsson, K. (1995). Comparison of the effect of the linseed extract Salinum and a methyl cellulose preparation on the symptoms of dry mouth. Gerodontology, 12(1), 12-17. https://doi.org/10.1111/j.1741-2358.1995.tb00124.x

Apperley, O., Medlicott, N., Rich, A., Hanning, S., \& Huckabee, M. L. (2017). A clinical trial of a novel emulsion for potential use as a saliva substitute in patients with radiationinduced xerostomia. Journal of Oral Rehabilitation, 44(11), 889-895. https://doi.org/10.1111/joor.12545

Blixt-Johansen, G., Sjöholm, K., Wiesel, K., \& Ek, A. C. (1992). The condition of the oral mucosa in institutionalized elderly patients before and after using a mucin-containing saliva substitute. Scandinavian Journal of Caring Sciences, 6(3), 147-150. https://doi.org/10.1111/j.1471-6712.1992.tb00142.x

Bots, C. P., Brand, H. S., Veerman, E. C. I., Korevaar, J. C., Valentijn-Benz, M., Bezemer, P. D., ... Nieuw Amerongen, A. V. (2005). Chewing gum and a saliva substitute alleviate thirst and xerostomia in patients on haemodialysis. Nephrology, Dialysis, Transplantation, 20(3), 578-584. https://doi.org/10.1093/ndt/gfh675

Chen, J. (2007). Food oral processing—A review. Food Hydrocolloids, 23, 1-25.

Cuschieri, S. (2019). The STROBE guidelines. Saudi Journal of Anaesthesia, 13(Suppl 1), S31-S34. PubMed (30930717). https://doi.org/10.4103/sja.SJA_543_18

Dalodom, S., Lam-Ubol, A., Jeanmaneechotechai, S., Takamfoo, L., Intachai, W., Duangchada, K., ... Trachootham, D. (2016). Influence of oral moisturizing jelly as a saliva substitute 
for the relief of xerostomia in elderly patients with hypertension and diabetes mellitus. Geriatric Nursing, 37(2), 101-109. https://doi.org/10.1016/j.gerinurse.2015.10.014

Davies, A. N., Daniels, C., Pugh, R., \& Sharma, K. (1998). A comparison of artificial saliva and pilocarpine in the management of xerostomia in patients with advanced cancer. Palliative Medicine, 12(2), 105-111. https://doi.org/10.1191/026921698670435903

Davies, A. N., \& Singer, J. (1994). A comparison of artificial saliva and pilocarpine in radiationinduced xerostomia. The Journal of Laryngology and Otology, 108(8), 663-665. https://doi.org/10.1017/s0022215100127768

Dirix, P., Nuyts, S., Vander Poorten, V., Delaere, P., \& Van den Bogaert, W. (2007). Efficacy of the BioXtra dry mouth care system in the treatment of radiotherapy-induced xerostomia. Supportive Care in Cancer, 15(12), 1429-1436. https://doi.org/10.1007/s00520-006-0210-y

Donath, F., Tonner, F., Chavda, R., Gatignol, J.-P., \& Bouyrie, J. (2016). Randomized trial of the efficacy and safety of a new oral spray for drug-induced xerostomia. Clinical and Experimental Dental Research, 2(2), 112-120. https://doi.org/10.1002/cre2.29

Duxbury, A. J., Thakker, N. S., \& Wastell, D. G. (1989). A double-blind cross-over trial of a mucin-containing artificial saliva. British Dental Journal, 166(4), 115-120. https://doi.org/10.1038/sj.bdj.4806731

Epstein, J., Emerton, S., Le, N. D., \& Stevenson-Moore, P. (1999). A double-blind crossover trial of Oral Balance gel and Biotene ${ }^{\circledR}$ toothpaste versus placebo in patients with xerostomia following radiation therapy. Oral Oncology, 35(2), 132-137. https://doi.org/10.1016/S1368-8375(98)00109-2

Epstein, J., \& Stevenson-Moore, P. (1992). A clinical comparative trial of saliva substitutes in radiation-induced salivary gland hypofunction. Special Care in Dentistry, 12(1), 21-23. https://doi.org/10.1111/j.1754-4505.1992.tb00401.x 
Epstein, J., Thariat, J., Bensadoun, R.-J., Barasch, A., Murphy, B. A., Kolnick, L., ... Maghami, E. (2012). Oral complications of cancer and cancer therapy: From cancer treatment to survivorship. CA: A Cancer Journal for Clinicians, 62(6), 400-422. https://doi.org/10.3322/caac.21157

Fox, P. C., Busch, K. A., \& Baum, B. J. (1987). Subjective reports of xerostomia and objective measures of salivary gland performance. Journal of the American Dental Association, 115(4), 581-584. https://doi.org/10.1016/s0002-8177(87)54012-0

Frost, P. M., Shirlaw, P. J., Walter, J. D., \& Challacombe, S. J. (2002). Patient preferences in a preliminary study comparing an intra-oral lubricating device with the usual dry mouth lubricating methods. British Dental Journal, 193(7), 403-408. https://doi.org/10.1038/sj.bdj.4801576

Furness, S., Bryan, G., McMillan, R., Birchenough, S., \& Worthington, H. V. (2013). Interventions for the management of dry mouth: Non-pharmacological interventions. The Cochrane Database of Systematic Reviews, (9), CD009603. https://doi.org/10.1002/14651858.CD009603.pub3

Furness, S., Worthington, H. V., Bryan, G., Birchenough, S., \& McMillan, R. (2011). Interventions for the management of dry mouth: Topical therapies. The Cochrane Database of Systematic Reviews, (12), CD008934. https://doi.org/10.1002/14651858.CD008934.pub2

Furumoto, E. K., Barker, G. J., Carter-Hanson, C., \& Barker, B. F. (1998). Subjective and clinical evaluation of oral lubricants in xerostomic patients. Special Care in Dentistry, 18(3), 113-118. https://doi.org/10.1111/j.1754-4505.1998.tb00915.x

Gil-Montoya, J. A., Subirá, C., Ramón, J. M., \& González-Moles, M. A. (2008). Oral healthrelated quality of life and nutritional status. Journal of Public Health Dentistry, 68(2), 88-93. https://doi.org/10.1111/j.1752-7325.2007.00082.x 
Hägglund, P., Blom, S., Thoden, P., \& Karlsson, F. (2020). The Test of Masticating and Swallowing Solids (TOMASS): Normative data for two crackers available in the Scandinavian and international markets. International Journal of Speech-Language Pathology, 1-9. https://doi.org/10.1080/17549507.2020.1800090

Hahnel, S., Behr, M., Handel, G., \& Bürgers, R. (2009). Saliva substitutes for the treatment of radiation-induced xerostomia_A review. Supportive Care in Cancer, 17(11), 13311343. https://doi.org/10.1007/s00520-009-0671-x

Heydarirad, G., Rezaeizadeh, H., Choopani, R., Mosavat, S. H., \& Ameri, A. (2017). Efficacy of a traditional Persian medicine preparation for radiation-induced xerostomia: A randomized, open-label, active-controlled trial. Journal of Integrative Medicine, 15(3), 201-208. https://doi.org/10.1016/S2095-4964(17)60333-9

Hopcraft, M., \& Tan, C. (2010). Xerostomia: An update for clinicians. Australian Dental Journal, 55(3), 238-244. https://doi.org/10.1111/j.1834-7819.2010.01229.x

Huckabee, M.-L., McIntosh, T., Fuller, L., Curry, M., Thomas, P., Walshe, M., ... Sella-Weiss, O. (2018). The Test of Masticating and Swallowing Solids (TOMASS): Reliability, validity and international normative data. International Journal of Language \& Communication Disorders, 53(1), 144-156. https://doi.org/10.1111/1460-6984.12332

Iwasaki, M., Yoshihara, A., Ito, K., Sato, M., Minagawa, K., Muramatsu, K., ... Miyazaki, H. (2016). Hyposalivation and dietary nutrient intake among community-based older Japanese. Geriatrics \& Gerontology International, 16(4), 500-507. https://doi.org/10.1111/ggi.12500

Jellema, A. P., Langendijk, H., Bergenhenegouwen, L., van der Reijden, W., Leemans, R., Smeele, L., \& Slotman, B. J. (2001). The efficacy of Xialine in patients with xerostomia resulting from radiotherapy for head and neck cancer: A pilot-study. Radiotherapy and Oncology, 59(2), 157-160. https://doi.org/10.1016/s0167-8140(01)00336-х 
Johansson, G., Andersson, G., Attström, R., Glantz, P. O., \& Larsson, K. (1994). The effect of Salinum on the symptoms of dry mouth: A pilot study. Gerodontology, 11(1), 46-49. https://doi.org/10.1111/j.1741-2358.1994.tb00102.x

Klestov, A. C., Webb, J., Latt, D., Schiller, G., McNamara, K., Young, D. Y., ... Fetherston, J. (1981). Treatment of xerostomia: A double-blind trial in 108 patients with Sjögren’s syndrome. Oral Surgery, Oral Medicine, and Oral Pathology, 51(6), 594-599. https://doi.org/10.1016/s0030-4220(81)80008-4

Krop, E. M., Hetherington, M. M., Nekitsing, C., Miquel, S., Postelnicu, L., \& Sarkar, A. (2018). Influence of oral processing on appetite and food intake-A systematic review and meta-analysis. Appetite, 125, 253-269. https://doi.org/10.1016/j.appet.2018.01.018 LeVeque, F. G., Montgomery, M., Potter, D., Zimmer, M. B., Rieke, J. W., Steiger, B. W., ... Muscoplat, C. C. (1993). A multicenter, randomized, double-blind, placebo-controlled, dose-titration study of oral pilocarpine for treatment of radiation-induced xerostomia in head and neck cancer patients. Journal of Clinical Oncology, 11(6), 1124-1131. https://doi.org/10.1200/JCO.1993.11.6.1124

Liedberg, B., Ekberg, O., \& Owall, B. (1991). Chewing and the dimension of the pharyngoesophageal segment. Dysphagia, 6(4), 214-218. https://doi.org/10.1007/bf02493530

Longman, L. P., Higham, S. M., Bucknall, R., Kaye, S. B., Edgar, W. M., \& Field, E. A. (1997). Signs and symptoms in patients with salivary gland hypofunction. Postgraduate Medical Journal, 73(856), 93-97. https://doi.org/10.1136/pgmj.73.856.93

Łysik, D., Niemirowicz-Laskowska, K., Bucki, R., Tokajuk, G., \& Mystkowska, J. (2019). Artificial Saliva: Challenges and Future Perspectives for the Treatment of Xerostomia. International Journal of Molecular Sciences, 20(13), 3199. https://doi.org/10.3390/ijms20133199 
Matear, D. W., \& Barbaro, J. (2005). Effectiveness of saliva substitute products in the treatment of dry mouth in the elderly: A pilot study. The Journal of the Royal Society for the Promotion of Health, 125(1), 35-41. https://doi.org/10.1177/146642400512500113

McMillan, A. S., Tsang, C. S. P., Wong, M. C. M., \& Kam, A. Y. L. (2006). Efficacy of a novel lubricating system in the management of radiotherapy-related xerostomia. Oral Oncology, 42(8), 842-848. https://doi.org/10.1016/j.oraloncology.2005.12.003

Moher, D., Shamseer, L., Clarke, M., Ghersi, D., Liberati, A., Petticrew, M., ... PRISMA-P Group. (2015). Preferred reporting items for systematic review and meta-analysis protocols (PRISMA-P) 2015 statement. Systematic Reviews, 4, 1. https://doi.org/10.1186/2046-4053-4-1

Momm, F., \& Guttenberger, R. (2002). Treatment of xerostomia following radiotherapy: Does age matter? Supportive Care in Cancer, 10(6), 505-508. https://doi.org/10.1007/s00520-002-0362-3

Momm, F., Volegova-Neher, N. J., Schulte-Mönting, J., \& Guttenberger, R. (2005). Different saliva substitutes for treatment of xerostomia following radiotherapy. A prospective crossover study. Strahlentherapie Und Onkologie, 181(4), 231-236. https://doi.org/10.1007/s00066-005-1333-7

Morales-Bozo, I., Ortega-Pinto, A., Rojas Alcayaga, G., Aitken Saavedra, J. P., Salinas Flores, O., Lefimil Puente, C., ... Urzúa Orellana, B. (2017). Evaluation of the effectiveness of a chamomile (Matricaria chamomilla) and linseed (Linum usitatissimum) saliva substitute in the relief of xerostomia in elders. Gerodontology, 34(1), 42-48. https://doi.org/10.1111/ger.12220

Mouly, S., Orler, J.-B., Tillet, Y., Coudert, A.-C., Oberli, F., Preshaw, P., \& Bergmann, J.-F. (2007). Efficacy of a new oral lubricant solution in the management of psychotropic 
drug-induced xerostomia: A randomized controlled trial. Journal of Clinical Psychopharmacology, 27(5), 437-443. https://doi.org/10.1097/jcp.0b013e31814db434 Mouly, S., Salom, M., Tillet, Y., Coudert, A.-C., Oberli, F., Preshaw, P. M., ... Bergmann, J.F. (2007). Management of xerostomia in older patients: A randomised controlled trial evaluating the efficacy of a new oral lubricant solution. Drugs \& Aging, 24(11), 957965. https://doi.org/10.2165/00002512-200724110-00007

Nakamoto, R. Y. (1979). Use of a saliva substitute in postradiation xerostomia. The Journal of Prosthetic Dentistry, 42(5), 539-542. https://doi.org/10.1016/0022-3913(79)90249-x

Navazesh, M., Christensen, C., \& Brightman, V. (1992). Clinical criteria for the diagnosis of salivary gland hypofunction. Journal of Dental Research, 71(7), 1363-1369. https://doi.org/10.1177/00220345920710070301

Oh, D. J., Lee, J. Y., Kim, Y. K., \& Kho, H. S. (2008). Effects of carboxymethylcellulose (CMC)-based artificial saliva in patients with xerostomia. International Journal of Oral and Maxillofacial Surgery, 37(11), 1027-1031. https://doi.org/10.1016/j.ijom.2008.06.006

Porter, S. R., Scully, C., \& Hegarty, A. M. (2004). An update of the etiology and management of xerostomia. Oral Surgery, Oral Medicine, Oral Pathology, Oral Radiology, and Endodontics, 97(1), 28-46. https://doi.org/10.1016/j.tripleo.2003.07.010

Prinz, J. F., \& Lucas, P. W. (1997). An optimization model for mastication and swallowing in mammals. Proceedings. Biological Sciences, 264(1389), 1715-1721. https://doi.org/10.1098/rspb.1997.0238

Regelink, G., Vissink, A., Reintsema, H., \& Nauta, J. M. (1998). Efficacy of a synthetic polymer saliva substitute in reducing oral complaints of patients suffering from irradiation-induced xerostomia. Quintessence International, 29(6), 383-388. 
Rogus-Pulia, N. M., Gangnon, R., Kind, A., Connor, N. P., \& Asthana, S. (2018). A Pilot Study of Perceived Mouth Dryness, Perceived Swallowing Effort, and Saliva Substitute Effects in Healthy Adults Across the Age Range. Dysphagia, 33(2), 200-205. https://doi.org/10.1007/s00455-017-9846-7

Salom, M., Hachulla, E., Bertolus, C., Deschaumes, C., Simoneau, G., \& Mouly, S. (2015). Efficacy and safety of a new oral saliva equivalent in the management of xerostomia: A national, multicenter, randomized study. Oral Surgery, Oral Medicine, Oral Pathology and Oral Radiology, 119(3), 301-309. https://doi.org/10.1016/j.oooo.2014.12.005

Shahdad, S. A., Taylor, C., Barclay, S. C., Steen, I. N., \& Preshaw, P. M. (2005). A doubleblind, crossover study of Biotène Oralbalance and BioXtra systems as salivary substitutes in patients with post-radiotherapy xerostomia. European Journal of Cancer Care, 14(4), 319-326. https://doi.org/10.1111/j.1365-2354.2005.00587.x

Ship, J. A., DeCarli, C., Friedland, R. P., \& Baum, B. J. (1990). Diminished submandibular salivary flow in dementia of the Alzheimer type. Journal of Gerontology, 45(2), M6166.

Silvestre, F. J., Minguez, M. P., \& Suñe-Negre, J. M. (2009). Clinical evaluation of a new artificial saliva in spray form for patients with dry mouth. Medicina Oral, Patologia Oral Y Cirugia Bucal, 14(1), E8-E11.

Skrinjar, I., Vucicevic Boras, V., Bakale, I., Andabak Rogulj, A., Brailo, V., Vidovic Juras, D., ... Vrdoljak, D. V. (2015). Comparison between three different saliva substitutes in patients with hyposalivation. Clinical Oral Investigations, 19(3), 753-757. https://doi.org/10.1007/s00784-015-1405-8

Sreebny, L. M. (2000). Saliva in health and disease: An appraisal and update. International Dental Journal, 50(3), 140-161. https://doi.org/10.1111/j.1875-595x.2000.tb00554.x 
Stewart, C. M., Jones, A. C., Bates, R. E., Sandow, P., Pink, F., \& Stillwell, J. (1998). Comparison between saliva stimulants and a saliva substitute in patients with xerostomia and hyposalivation. Special Care in Dentistry, 18(4), 142-148. https://doi.org/10.1111/j.1754-4505.1998.tb01136.x

Sweeney, M. P., Bagg, J., Baxter, W. P., \& Aitchison, T. C. (1997). Clinical trial of a mucincontaining oral spray for treatment of xerostomia in hospice patients. Palliative Medicine, 11(3), 225-232. https://doi.org/10.1177/026921639701100307

Temmel, A. F. P., Quint, C., Schickinger-Fischer, B., \& Hummel, T. (2005). Taste function in xerostomia before and after treatment with a saliva substitute containing carboxymethylcellulose. The Journal of Otolaryngology, 34(2), 116-120. https://doi.org/10.2310/7070.2005.04008

van der Reijden, W. A., van der Kwaak, H., Vissink, A., Veerman, E. C., \& Amerongen, A. V. (1996). Treatment of xerostomia with polymer-based saliva substitutes in patients with Sjögren's syndrome. Arthritis and Rheumatism, 39(1), 57-63. https://doi.org/10.1002/art.1780390108

Visch, L. L., Gravenmade, E. J., Schaub, R. M., Van Putten, W. L., \& Vissink, A. (1986). A double-blind crossover trial of CMC- and mucin-containing saliva substitutes. International Journal of Oral and Maxillofacial Surgery, 15(4), 395-400. https://doi.org/10.1016/s0300-9785(86)80027-8

Vissink, A., Burlage, F. R., Spijkervet, F. K., Veerman, E. C. I., \& Nieuw Amerongen, A. V. (2004). Prevention and treatment of salivary gland hypofunction related to head and neck radiation therapy and chemotherapy. Supportive Cancer Therapy, 1(2), 111-118. https://doi.org/10.3816/SCT.2004.n.004

Vissink, A., s-Gravenmade, E. J., Panders, A. K., Vermey, A., Petersen, J. K., Visch, L. L., \& Schaub, R. M. (1983). A clinical comparison between commercially available mucin- 
and CMC-containing saliva substitutes. International Journal of Oral Surgery, 12(4), 232-238. https://doi.org/10.1016/s0300-9785(83)80048-9 
Table 1: Aetiologies for xerostomia and criteria for evaluation of FOP funtions in included studies

\begin{tabular}{|c|c|c|c|c|}
\hline Studies & Xerostomia aetiology & 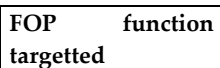 & Objectives measures & Subjectives measures \\
\hline (Aliko et al., 2012) & Sjögren's Syndrome & $\begin{array}{l}\text { Mastication } \\
\text { Swallowing } \\
\text { Taste }\end{array}$ & $\begin{array}{l}\text { Salivary flow } \\
\text { Quantity of SS' use }\end{array}$ & VAS \\
\hline (Alpöz et al., 2008) & Sjögren's Syndrome & \begin{tabular}{|l} 
Taste \\
Mastication \\
Siping \\
Speech \\
Swallowing
\end{tabular} & Salivary flow & VAS \\
\hline (Alpöz et al., 2015) & Mixed, unspecified & \begin{tabular}{|l|} 
Chewing \\
Sipping \\
Swallowing \\
Taste \\
\end{tabular} & $\begin{array}{l}\text { Salivary flow } \\
\text { Oral examination }\end{array}$ & Questionnaire \\
\hline (Alves et al., 2004) & Sjögren's syndrome & $\begin{array}{l}\text { Mastication } \\
\text { Swallowing }\end{array}$ & Salivary flow & Questionnaire \\
\hline (Andersson et al., 1995) & Radiotherapy & $\begin{array}{l}\text { Chewing } \\
\text { Swallowing } \\
\text { Taste }\end{array}$ & $\begin{array}{l}\text { Oral examination } \\
\text { Salivary flow }\end{array}$ & Questionnaire \\
\hline (Apperley et al., 2017) & Radiotherapy & $\begin{array}{l}\text { Mastication } \\
\text { Swallowing }\end{array}$ & $\begin{array}{l}\text { Chewing cycles } \\
\text { Chewing time } \\
\text { Swallows/bite } \\
\text { (TOMASS) } \\
\end{array}$ & Questionnaire \\
\hline $\begin{array}{l}\text { (Blixt-Johansen et al., } \\
\text { 1992) }\end{array}$ & $\begin{array}{l}\text { Drugs } \\
\text { Other unspecified }\end{array}$ & \begin{tabular}{|l} 
Eating \\
Swallowing
\end{tabular} & Oral examination & $\begin{array}{l}\text { Reports of frequency } \\
\text { by Staff }\end{array}$ \\
\hline (Bots et al., 2005) & Kidney failure & ND & Salivary flow & Questionnaire \\
\hline (Dalodom et al., 2016) & $\begin{array}{l}\text { Mellitous diabetes } \\
\text { Hypertension }\end{array}$ & $\begin{array}{l}\text { Chewing } \\
\text { Swallowing } \\
\text { Taste disturbance }\end{array}$ & $\begin{array}{l}\text { Oral examination } \\
\text { Salivary flow }\end{array}$ & VAS \\
\hline (Davies \& Singer, 1994) & Radiotherapy & $\begin{array}{l}\text { Dysphagia } \\
\text { Dysgeusia }\end{array}$ & ND & $\begin{array}{l}\text { Questionnaire } \\
\text { VAS }\end{array}$ \\
\hline (Davies et al., 1998) & Cancer & $\begin{array}{l}\text { Dysphagia } \\
\text { Dysgeusia }\end{array}$ & ND & $\begin{array}{l}\text { Questionnaire } \\
\text { VAS }\end{array}$ \\
\hline (Dirix et al., 2007) & Radiotherapy & $\begin{array}{l}\text { Swallowing } \\
\text { Taste }\end{array}$ & ND & $\begin{array}{l}\text { Questionnaire } \\
\text { VAS }\end{array}$ \\
\hline (Donath et al., 2016) & Drugs & Swallowing & $\begin{array}{l}\text { Oral examination } \\
\text { Salivary flow }\end{array}$ & VAS \\
\hline (Duxbury et al., 1989) & \begin{tabular}{|l} 
Drugs \\
Diabetes \\
Radiotherapy \\
Sjögren's syndrome \\
Smoking
\end{tabular} & $\begin{array}{l}\text { Eating } \\
\text { Taste }\end{array}$ & $\begin{array}{l}\text { Frequency of SS' use } \\
\text { Salivary flow }\end{array}$ & VAS \\
\hline $\begin{array}{l}\text { (Epstein \& Stevenson- } \\
\text { Moore, 1992) }\end{array}$ & Radiotherapy & ND & $\begin{array}{l}\text { Frequency of SS' use } \\
\text { Salivary flow }\end{array}$ & Questionnaire \\
\hline (Epstein et al., 1999) & Radiotherapy & $\begin{array}{l}\text { Swallowing } \\
\text { Taste }\end{array}$ & Salivary flow & VAS \\
\hline (Frost et al., 2002) & $\begin{array}{l}\text { Buccal respiration } \\
\text { Drugs } \\
\text { Sjögren's syndrome } \\
\text { Other }\end{array}$ & $\begin{array}{l}\text { Chewing } \\
\text { Swallowing }\end{array}$ & $\begin{array}{l}\text { Oral examination } \\
\text { Salivary flow }\end{array}$ & Questionnaire \\
\hline (Furumoto et al., 1998) & Mixed, unspecified & Eating & Salivary flow & Questionnaire \\
\hline
\end{tabular}




\begin{tabular}{|c|c|c|c|c|}
\hline & & Swallowing & & \\
\hline $\begin{array}{l}\text { (Gil-Montoya et al., } \\
2008)\end{array}$ & Aging & \begin{tabular}{|l|} 
Biting \\
Chewing \\
Eating \\
Swallowing \\
\end{tabular} & ND & Questionnaire \\
\hline $\begin{array}{l}\text { (Heydarirad et al., } \\
\text { 2017) }\end{array}$ & Radiotherapy & \begin{tabular}{|l} 
Eating \\
Swallowing \\
Taste \\
\end{tabular} & ND & Questionnaire \\
\hline (Jellema et al., 2001) & Radiotherapy & Swallowing & Frequency of SS' use & Questionnaires \\
\hline (Johansson et al., 1994) & \begin{tabular}{|l} 
Drugs \\
Radiotherapy \\
Sjögren's Syndrome \\
\end{tabular} & $\begin{array}{l}\text { Mastication } \\
\text { Swallowing } \\
\text { Taste }\end{array}$ & Oral examination & Questionnaire \\
\hline (Klestov et al., 1981) & Sjogren's syndrome & $\begin{array}{l}\text { Chewing } \\
\text { Drinking } \\
\text { Swallowing } \\
\end{array}$ & ND & Questionnaire \\
\hline $\begin{array}{l}\text { (Matear \& Barbaro, } \\
\text { 2005) }\end{array}$ & \begin{tabular}{|l} 
Aging \\
Drugs \\
Systemic diseases \\
\end{tabular} & Swallowing & ND & Questionnaire \\
\hline (McMillan et al., 2006) & Radiotherapy & \begin{tabular}{|l|} 
Biting \\
Chewing \\
Eating \\
Swallowing \\
\end{tabular} & Salivary flow & Questionnaire \\
\hline (Momm et al., 2005) & Radiotherapy & $\begin{array}{l}\text { Chewing } \\
\text { Eating } \\
\text { Swallowing } \\
\end{array}$ & ND & Questionnaire \\
\hline $\begin{array}{l}\text { (Morales-Bozo et al., } \\
\text { 2017) }\end{array}$ & Various & Swallowing & Salivary flow & VAS \\
\hline $\begin{array}{l}\text { (Mouly, Orler, et al., } \\
2007 \text { ) }\end{array}$ & Aging & $\begin{array}{l}\text { Chewing } \\
\text { Swallowing } \\
\text { Taste }\end{array}$ & $\begin{array}{l}\text { Oral examination } \\
\text { Salivary flow }\end{array}$ & VAS \\
\hline $\begin{array}{l}\text { (Mouly, Salom, et al., } \\
\text { 2007) }\end{array}$ & Drugs & $\begin{array}{l}\text { Chewing } \\
\text { Swallowing } \\
\text { Taste } \\
\end{array}$ & $\begin{array}{l}\text { Frequency of SS' use } \\
\text { Oral examination } \\
\text { Salivary flow }\end{array}$ & $\begin{array}{l}\text { Questionnaire } \\
\text { VAS }\end{array}$ \\
\hline (Nakamoto, 1979) & Radiotherapy & $\begin{array}{l}\text { Eating } \\
\text { Swallowing } \\
\text { Taste } \\
\end{array}$ & ND & Questionnaire \\
\hline (Oh et al., 2008) & $\begin{array}{l}\text { Sjögren's syndrome } \\
\text { Autoimmune disorders } \\
\text { Radiotherapy }\end{array}$ & \begin{tabular}{|l|} 
Chewing \\
Eating \\
Sipping \\
Swallowing \\
\end{tabular} & Salivary flow & Questionnaire \\
\hline (Regelink et al., 1998) & Radiotherapy & & \begin{tabular}{|l|} 
Salivary flow \\
\end{tabular} & Questionnaire \\
\hline $\begin{array}{l}\text { (Rogus-Pulia et al., } \\
2018)\end{array}$ & Aging & Swallowing & ND & One single questior \\
\hline (Salom et al., 2015) & $\begin{array}{l}\text { Autoimmune disorders } \\
\text { Drugs } \\
\text { Radiotherapy } \\
\text { Sjögren's syndrome } \\
\text { Other various medical } \\
\text { conditions } \\
\end{array}$ & $\begin{array}{l}\text { Chewing } \\
\text { Swallowing } \\
\text { Taste }\end{array}$ & ND & $\begin{array}{l}\text { Questionnaire } \\
\text { VAS }\end{array}$ \\
\hline (Shahdad et al., 2005) & Radiotherapy & $\begin{array}{l}\text { Chewing } \\
\text { Swallowing } \\
\text { Taste } \\
\end{array}$ & ND & $\begin{array}{l}\text { Questionnaire } \\
\text { VAS }\end{array}$ \\
\hline (Silvestre et al., 2009) & \begin{tabular}{|l|} 
Drugs \\
Radiotherapy \\
\end{tabular} & \begin{tabular}{|l|} 
Eating \\
Swallowing \\
\end{tabular} & $\begin{array}{l}\text { Frequency of SS' use } \\
\text { Salivary flow }\end{array}$ & VAS \\
\hline (Skrinjar et al., 2015) & Drugs & \begin{tabular}{|l|} 
Taste \\
Mastication
\end{tabular} & Salivary flow & $\begin{array}{l}\text { Questionnaire } \\
\text { VAS }\end{array}$ \\
\hline
\end{tabular}




\begin{tabular}{|l|l|l|l|l|}
\hline (Stewart et al., 1998) & $\begin{array}{l}\text { Auto-immune disease } \\
\text { Drugs } \\
\text { Radiotherapy }\end{array}$ & $\begin{array}{l}\text { Eating } \\
\text { Sipping } \\
\text { Swallowing } \\
\text { Taste }\end{array}$ & Salivary flow & $\begin{array}{l}\text { Questionnaire } \\
\text { VAS }\end{array}$ \\
\hline (Sweeney et al., 1997) & $\begin{array}{l}\text { Motor neurone disease } \\
\text { cancer }\end{array}$ & Eating Taste & Salivary flow & VAS \\
\hline (Temmel et al., 2005) & $\begin{array}{l}\text { Sjögren's syndrome } \\
\text { Menopause }\end{array}$ & Taste & $\begin{array}{l}\text { Frequency of SS' use } \\
\text { Oral examination }\end{array}$ & Questionnaire \\
\hline $\begin{array}{l}\text { (van der Reijden et al.,, } \\
\text { 1996) }\end{array}$ & $\begin{array}{l}\text { Sjögren's syndrome } \\
\text { Autoimmune disorders }\end{array}$ & $\begin{array}{l}\text { Eating } \\
\text { Swallowing } \\
\text { Taste }\end{array}$ & Salivary flow & Questionnaire \\
\hline (Visch et al., 1986) & $\begin{array}{l}\text { Radiotherapy } \\
\text { Sjögren's syndrome }\end{array}$ & $\begin{array}{l}\text { Chewing } \\
\text { Swallowing }\end{array}$ & ND & Questionnaire \\
\hline (Vissink et al., 1983) & $\begin{array}{l}\text { Drugs } \\
\text { Radiotherapy } \\
\text { Sjögren's syndrome } \\
\text { Other unspecified }\end{array}$ & $\begin{array}{l}\text { Mastication } \\
\text { Swallowing } \\
\text { Taste }\end{array}$ & $\begin{array}{l}\text { Oral } \\
\text { Salivary presence }\end{array}$ & Questionnaire \\
\hline
\end{tabular}


Table 2 Composition of saliva substitute used in the included studies (NSS: Natural saliva simulators: saliva substitutes containing mucin or mucin with xanthan or guar gum

\begin{tabular}{|c|c|c|c|c|c|c|c|}
\hline Name & Composition & NSS & Form & Aromas & Instructions for use & Placebo or Control & References \\
\hline \multirow[t]{3}{*}{ Aequasyal ${ }^{\circledR}$} & \multirow[t]{3}{*}{$\begin{array}{l}94.4 \% \text { triesters of glycerol; } \\
\text { Oxidized fatty acids of } \\
\text { vegetal origin (corn oil) } \\
\text { Silicius dioxide } \\
\text { Aspartame }\end{array}$} & \multirow[t]{3}{*}{ No } & \multirow[t]{3}{*}{ Spray } & \multirow[t]{3}{*}{$\begin{array}{l}\text { Orange, } \\
\text { Grapefruit, } \\
\text { And mint } \\
\text { Aspartam }\end{array}$} & $\begin{array}{l}2 \text { spray (one by cheek then } \\
\text { swill the product with the } \\
\text { tongue until it had coated } \\
\text { oral mucosa, after } \\
\text { breakfast, and } 15 \text { min } \\
\text { before a standard meal }\end{array}$ & & $\begin{array}{l}\text { (Donath et al., } \\
\text { 2016) }\end{array}$ \\
\hline & & & & & At least 5 times/day & & $\begin{array}{l}\text { (Mouly, Orler, et } \\
\text { al., 2007) }\end{array}$ \\
\hline & & & & & $\begin{array}{l}1 \text { or } 2 \text { spray up to } 4 \text { times } \\
\text { a day }\end{array}$ & & $\begin{array}{l}\text { (Mouly, Salom, et } \\
\text { al., 2007) }\end{array}$ \\
\hline \multirow[t]{2}{*}{ Novasial ${ }^{\circledR}$} & & & Sticks & & One stick 4 times a day & & \multirow[t]{2}{*}{ (Salom et al., 2015) } \\
\hline & & & Spray & & $\begin{array}{l}\text { One sray four times a } \\
\text { week }\end{array}$ & $\begin{array}{l}\text { Aequasyal }{ }^{\circledR} \\
\text { Biotène }{ }^{\circledR}\end{array}$ & \\
\hline $\begin{array}{l}\text { DC161- } \\
\text { DP0293 }\end{array}$ & $\begin{array}{l}\text { Paraffin liquid, Cotton } \\
\text { refine oil, Alphatocopheryle } \\
\text { acetate (oily solution) }\end{array}$ & No & Spray & $\begin{array}{l}\text { Orange } \\
\text { flavor }\end{array}$ & $\begin{array}{l}3 \text { sprays (one by cheek, } \\
\text { one on the tongue,) twice a } \\
\text { day. One after breakfast, } \\
\text { and one } 15 \text { min before a } \\
\text { standard meal }\end{array}$ & & $\begin{array}{l}\text { (Donath et al., } \\
\text { 2016) }\end{array}$ \\
\hline $\begin{array}{l}\text { DC161- } \\
\text { DP0291 }\end{array}$ & $\begin{array}{l}\text { Glycerol, Polysorbate 80, } \\
\text { Soja lecithin, Sodium } \\
\text { hyaluronate, Xanthan gum, } \\
\text { Potassium chloride, Xylitol, } \\
\text { Anhydrous } \\
\text { disodiumhydrogen } \\
\text { phosphate, potassium } \\
\text { dihydrogen, phosphate, } \\
\text { sucralose, macrogolglycerol } \\
40 \text { hydroxystearate, } \\
\text { benzylic, alcohol, Sodium } \\
\text { benzoate, Cetylpyridinium } \\
\text { chloride, alpha, tocopheryle }\end{array}$ & Yes & Spray & $\begin{array}{l}\text { soft mint } \\
\text { flavor }\end{array}$ & $\begin{array}{l}3 \text { sprays (one by cheek, } \\
\text { one on the tongue,) twice a } \\
\text { day. One after breakfast, } \\
\text { and one } 15 \mathrm{~min} \text { before a } \\
\text { standard meal }\end{array}$ & & $\begin{array}{lll}\text { (Donath } & \text { et } & \text { al., } \\
\text { 2016) } & & \end{array}$ \\
\hline
\end{tabular}




\begin{tabular}{|c|c|c|c|c|c|c|c|}
\hline & $\begin{array}{l}\text { acetate, Water. (Aqueous } \\
\text { solution) }\end{array}$ & & & & & & \\
\hline $\begin{array}{l}\text { DC161- } \\
\text { DP0292 }\end{array}$ & $\begin{array}{l}\text { Glycerol, Povidone K30, } \\
\text { Copovidone, xanthan Gum, } \\
\text { Potassium chloride, Xylitol, } \\
\text { Marshmallow concentrated } \\
\text { hydroglycerined extract, } \\
\text { Anhydrous disodium } \\
\text { hydrogen phosphate, } \\
\text { potassium dihydrogen } \\
\text { phosphate, } \\
\text { Macrogolglycerol } 40 \\
\text { hydroxystearate, Potassium } \\
\text { sorbate, benzylic alcohol, } \\
\text { Water }\end{array}$ & Yes & Spray & & $\begin{array}{l}3 \text { sprays (one by cheek, } \\
\text { one on the tongue,) twice a } \\
\text { day. One after breakfast, } \\
\text { and one } 15 \text { min before a } \\
\text { standard meal }\end{array}$ & & $\begin{array}{lll}\text { (Donath } & \text { et } & \text { al., } \\
\text { 2016) } & & \end{array}$ \\
\hline \multirow[t]{2}{*}{$\begin{array}{l}\text { Biotene Oral } \\
\text { Balance }{ }^{\circledR}\end{array}$} & \multirow[t]{2}{*}{$\begin{array}{l}\text { Lactoperoxidase, Lysozyme } \\
\text { Glucose oxidase, } \\
\text { Lactoferrin, Hydrogenated } \\
\text { starch, Polymethacrylate, } \\
\text { Xylitol sweetening; } \\
\text { Hydroxyethyl sweetening } \\
\text { Cellulose, Potassium } \\
\text { thiocyanate, Aloe vera. }\end{array}$} & \multirow[t]{2}{*}{ No } & \multirow[t]{2}{*}{ Gel } & \multirow[t]{2}{*}{ Sweetening } & \multirow[t]{2}{*}{$\begin{array}{l}1 \mathrm{~cm} \text { of gel on tongue and } \\
\text { oral muccosa }\end{array}$} & & $\begin{array}{l}\text { (Aliko et al., 2012; } \\
\text { Frost et al., 2002; } \\
\text { Regelink et al., } \\
\text { 1998; Rogus-Pulia } \\
\text { et al., 2018; } \\
\text { Shahdad et al,, } \\
\text { 2005) }\end{array}$ \\
\hline & & & & & & $\begin{array}{l}\text { Carboxymethylen : } \\
0.8 \% \\
\text { Triethanolamine } \\
\text { Xylitol } \\
\text { Nipagim : } 0.3 \%\end{array}$ & (Alves et al., 2004) \\
\hline \multirow[t]{2}{*}{$\begin{array}{l}\text { Biotene } \\
\text { mouthwash }{ }^{\circledR} \\
\text { and Oral } \\
\text { Balance gel }{ }^{\circledR}\end{array}$} & $\begin{array}{l}\text { Lactoperoxidase, } \\
\text { Lysozyme, Glucose oxidase, } \\
\text { Lactoferrin }\end{array}$ & & Mouthwash & $\begin{array}{l}\text { Slighly } \\
\text { mentholed } \\
\text { flavour and } \\
\text { xylitol } \\
\text { sweetening }\end{array}$ & $\begin{array}{l}\text { Three times a day after } \\
\text { brushing the teeth and/or } \\
\text { dentures }(12 \mathrm{ml}) \text { during } \\
30 \text { seconds }\end{array}$ & $\begin{array}{l}\text { Aqueous solution with } \\
\text { mint essence }\end{array}$ & \multirow[t]{2}{*}{$\begin{array}{l}\text { (Gil-Montoya et al., } \\
\text { 2008) }\end{array}$} \\
\hline & & & Gel & & $\begin{array}{l}\text { Following the mouthrinse, } \\
1 \mathrm{~cm} \text { of gel on tongue and } \\
\text { oral muccosa }\end{array}$ & $\begin{array}{l}\text { Cream of similar } \\
\text { appearance and flavor } \\
\text { was prepared using } \\
\text { carboxymethyl } \\
\text { cellulose }\end{array}$ & \\
\hline
\end{tabular}




\begin{tabular}{|c|c|c|c|c|c|c|c|}
\hline $\begin{array}{l}\text { Oral Balance } \\
\text { gel and Biotene } \\
\text { toothpaste }{ }^{\circledR}\end{array}$ & & No & $\begin{array}{l}\text { Gel } \\
\text { Toothpaste }\end{array}$ & & & $\begin{array}{l}\text { CMC gel and } \\
\text { commercial toothpaste }\end{array}$ & $\begin{array}{l}\text { (Epstein et al., } \\
\text { 1999) }\end{array}$ \\
\hline $\begin{array}{l}\text { Oral Balance } \\
\text { gel and Biotene } \\
\text { toothpaste and } \\
\text { Mounthwash }{ }^{\circledR} \\
\end{array}$ & & No & $\begin{array}{l}\text { Gel } \\
\text { Toothpaste } \\
\text { Mouthwash }\end{array}$ & & & & $\begin{array}{l}\text { (Matear \& Barbaro, } \\
\text { 2005; Shahdad et } \\
\text { al., 2005) }\end{array}$ \\
\hline \multirow{2}{*}{$\begin{array}{l}\text { Devicer and } \\
\text { Oral Balance } \\
\text { gel }\end{array}$} & & \multirow[t]{2}{*}{ No } & \multirow[t]{2}{*}{ Gel } & & At night & & (Frost et al., 2002) \\
\hline & & & & & $\begin{array}{l}\text { Gel alone in the form of } \\
\text { an oral bolus } \\
\text { Gel on demand via an } \\
\text { intra-oral device(at least } \\
\text { 4hours per day and } \\
\text { remove it at night) }\end{array}$ & & $\begin{array}{l}\text { (McMillan et al., } \\
\text { 2006) }\end{array}$ \\
\hline \multirow[t]{3}{*}{ Xialine ${ }^{\circledR}$} & \multirow[t]{3}{*}{$\begin{array}{l}\text { Polysaccharide xanthan } \\
\text { gum, sodium fluoride }\end{array}$} & \multirow[t]{3}{*}{ Yes } & \multirow[t]{3}{*}{ Spray } & Mint-taste & At least 6 times a day & $\begin{array}{l}\text { Water } \\
\text { Dilued tea }\end{array}$ & (Alpöz et al., 2008) \\
\hline & & & & Mint-taste & At least 6 times/ day & & (Bots et al., 2005) \\
\hline & & & & Neutral taste & At least 4 times a day & $\begin{array}{l}\text { Xialine without } \\
\text { Xanthan gum }\end{array}$ & $\begin{array}{l}\text { (Jellema } \\
\text { 2001) }\end{array}$ \\
\hline $\begin{array}{l}\text { Xanthan gum } \\
\text { high viscosity }\end{array}$ & $\begin{array}{l}\mathrm{KCl}, \mathrm{NaCl}, \mathrm{MgCl} 2, \mathrm{CaCl} \text {, } \\
\text { Methylhydroxybenzoate, } \\
\text { Benzalkonium chloride, } \\
\text { Keltrol KTL, Distilled water }\end{array}$ & Yes & & $\begin{array}{l}\text { Peppermint } \\
\text { flavour }\end{array}$ & & & $\begin{array}{l}\text { (van der Reijden et } \\
\text { al., 1996) }\end{array}$ \\
\hline $\begin{array}{l}\text { Xanthan gum } \\
\text { low viscosity }\end{array}$ & $\begin{array}{l}\mathrm{KCl}, \mathrm{NaCl}, \mathrm{MgCl} 2, \mathrm{CaCl} 2 \text {, } \\
\text { Methylhydroxybenzoate, } \\
\text { Benzalkonium chlorid, } \\
\text { Keltrol KTL, Distilled water }\end{array}$ & Yes & & $\begin{array}{l}\text { Peppermint } \\
\text { flavour }\end{array}$ & & & $\begin{array}{l}\text { (van der Reijden et } \\
\text { al., 1996) }\end{array}$ \\
\hline $\begin{array}{l}\text { Polyacrylic } \\
\text { acide }\end{array}$ & $\begin{array}{l}\mathrm{KCl}, \mathrm{NaCl}, \mathrm{MgCl} 2, \mathrm{CaCl} 2 \text {, } \\
\text { Methylhydroxybenzoate, } \\
\text { Benzalkonium chloride, } \\
\text { Carbopol, Distilled water }\end{array}$ & No & & $\begin{array}{l}\text { Peppermint } \\
\text { flavour }\end{array}$ & & & $\begin{array}{l}\text { (van der Reijden et } \\
\text { al., 1996) }\end{array}$ \\
\hline $\begin{array}{l}\text { Saliva } \\
\text { Orthana }{ }^{\circledR}\end{array}$ & $\begin{array}{l}\text { Mucin, xylitol, Potassium } \\
\text { chloride, sodium chloride, }\end{array}$ & Yes & Mouthwash & $\begin{array}{l}\text { Neutral- } \\
\text { tasting }\end{array}$ & $\begin{array}{l}\text { Rince }+ \text { swallow with } 5 \mathrm{ml} \\
3 \text { times/day before meal }\end{array}$ & & $\begin{array}{l}\text { (Blixt-Johansen et } \\
\text { al., 1992) }\end{array}$ \\
\hline
\end{tabular}




\begin{tabular}{|c|c|c|c|c|c|c|c|}
\hline & \multirow[t]{6}{*}{$\begin{array}{l}\text { magnésium, calcium, } \\
\text { dipotassium } \\
\text { hydorgenophosphate, } \\
\text { Methagine, } \\
\text { Benzalconchloride, } \\
\text { Sodium-EDTA }\end{array}$} & & & \multirow{3}{*}{$\begin{array}{l}\text { Peppermint } \\
\text { flavor } \\
\\
\begin{array}{l}\text { Peppermint } \\
\text { flavor }\end{array}\end{array}$} & Ad libitum & \multirow[t]{2}{*}{$\begin{array}{l}\mathrm{KCl}, \mathrm{NaCl}, \mathrm{MgCl} 2, \mathrm{CaC} \\
\mathrm{l2} \text {, } \\
\text { methylhydroxybenzoat } \\
\text { e, benzlkonium } \\
\text { chloride, distilled } \\
\text { water }\end{array}$} & \multirow[t]{2}{*}{$\begin{array}{l}\text { (van der Reijden et } \\
\text { al., 1996) } \\
\text { (Visch et al., 1986) }\end{array}$} \\
\hline & & & & & & & \\
\hline & & & & & Ad libitum & & 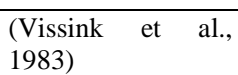 \\
\hline & & & \multirow[t]{3}{*}{ Spray } & $\begin{array}{l}\text { Peppermint } \\
\text { flavor }\end{array}$ & \multirow[t]{2}{*}{ 2-3 sprays when required } & $\begin{array}{l}\text { Saliva Orthana }{ }^{\circledR} \text { its } \\
\text { no-mucin base } \\
\text { Flavored distilled } \\
\text { water }\end{array}$ & $\begin{array}{l}\text { (Duxbury et al., } \\
\text { 1989) }\end{array}$ \\
\hline & & & & & & & \multirow{2}{*}{$\begin{array}{l}\text { (Davies et al., 1998; } \\
\text { Davies \& Singer, } \\
\text { 1994; Sweeney et } \\
\text { al., 1997) }\end{array}$} \\
\hline & & & & & At least twice per day & $\begin{array}{l}\text { Saliva Orthana }{ }^{\circledR} \text { its no- } \\
\text { mucin base }\end{array}$ & \\
\hline BioXtra ${ }^{\circledR}$ & $\begin{array}{l}\text { Hydroxyethylcellulose, } \\
\text { Polyglycerylmethacrylate, } \\
\text { Lactoperoxidase, Glucose } \\
\text { oxidase, Lactoferrin, } \\
\text { lysozyme and } \\
\text { Monofluorophosphate and } \\
\text { Xylitol (=oralbalance gel)+ } \\
\text { peptides and } \\
\text { Immunoglobulins }\end{array}$ & No & $\begin{array}{l}\text { System: } \\
\text { toothpaste } \\
\text { mouthwash } \\
\text { gel }\end{array}$ & $\begin{array}{l}\text { Sweetening } \\
\text { (less than } \\
\text { OB) }\end{array}$ & $\begin{array}{l}\text { Apply to your tongue and } \\
\text { gums with your fingertip } \\
\text { or a cotton swab Ad } \\
\text { libitum }\end{array}$ & & $\begin{array}{l}\text { (Dirix et al., 2007; } \\
\text { Shahdad et al., } \\
\text { 2005) }\end{array}$ \\
\hline $\begin{array}{l}\text { HCC Spray } \\
\text { Hydroxyethylc } \\
\text { ellulose citric } \\
\text { acid spray }\end{array}$ & & No & spray & & Ad libitum & & $\begin{array}{l}\text { (Furumoto et al., } \\
\text { 1998) }\end{array}$ \\
\hline $\begin{array}{l}\text { Hydroxyethylc } \\
\text { ellulose gel }\end{array}$ & & No & gel & & Ad libitum & & \\
\hline Salinum® ${ }^{\circledR}$ & $\begin{array}{l}\text { Linseed mucilage: } 54 \% \\
\text { Protein: } 9 \%\end{array}$ & & Mouthwash & & $\begin{array}{l}\text { Dosage of } 2 \mathrm{ml} \text { of fluid Ad } \\
\text { libitum }\end{array}$ & & $\begin{array}{l}\text { (Andersson et al., } \\
\text { 1995; Johansson et } \\
\text { al., 1994) }\end{array}$ \\
\hline
\end{tabular}




\begin{tabular}{|c|c|c|c|c|c|c|c|}
\hline Plant mucilage & $\begin{array}{lr}\begin{array}{l}\text { Matricaria } \\
\text { Linseed } \\
\text { usitatissimum) }\end{array} & \begin{array}{r}\text { chamomilla } \\
\text { (linum }\end{array} \\
\end{array}$ & & Mouthwash & & $2 \mathrm{ml} 4$ times a day & & $\begin{array}{l}\text { (Morales-Bozo et } \\
\text { al., 2017) }\end{array}$ \\
\hline \multirow{6}{*}{$\begin{array}{l}\text { Carboxyméthy } \\
\text { l Cellulose } \\
\text { (Original } \\
\text { preparations: } \\
\text { CMC, MAS- } \\
\text { 84, CMC-NZ, } \\
\text { CMC Spray) }\end{array}$} & \multirow[t]{6}{*}{$\begin{array}{l}\text { Sodium } \\
\text { carboxymethylcellulose }\end{array}$} & \multirow[t]{6}{*}{ No } & & \multirow{6}{*}{$\begin{array}{l}\text { Peppermint } \\
\text { flavor }\end{array}$} & Plastic bottle $2 \mathrm{ml}$ portion & & $\begin{array}{l}\text { (Andersson et al., } \\
\text { 1995; Apperley et } \\
\text { al., 2017) }\end{array}$ \\
\hline & & & & & $2 \mathrm{ml} 4$ times a day & & $\begin{array}{l}\text { (Morales-Bozo et } \\
\text { al., 2017; Temmel } \\
\text { et al., 2005) }\end{array}$ \\
\hline & & & & & Ad libitum & & (Visch et al., 1986) \\
\hline & & & & & Ad libitum & & $\begin{array}{l}\text { (Furumoto et al., } \\
1998 \text { ) }\end{array}$ \\
\hline & & & & & Ad libitum & & $\begin{array}{l}\text { (Vissink et al., } \\
\text { 1983) }\end{array}$ \\
\hline & & & & & 2ml Ad libitum & & (Oh et al., 2008) \\
\hline \multirow[t]{3}{*}{ VA-Oralube ${ }^{\circledR}$} & \multirow{2}{*}{$\begin{array}{l}\text { Carboxymethycellulose } \\
\text { Water } \\
\text { Sorbitol } \\
\text { Preservative } \\
\text { Fluorure, } \\
\text { Ions }\end{array}$} & \multirow[t]{3}{*}{ No } & \multirow{3}{*}{$\begin{array}{l}\text { Squeeze } \\
\text { bottle }\end{array}$} & & Ad libitum & & $\begin{array}{l}\text { (Epstein \& } \\
\text { Stevenson-Moore, } \\
\text { 1992) }\end{array}$ \\
\hline & & & & $\begin{array}{l}\text { Peppermint } \\
\text { flavor }\end{array}$ & Ad libitum & & $\begin{array}{l}\text { (Vissink et al., } \\
\text { 1983) }\end{array}$ \\
\hline & Dry concentrate & & & $\begin{array}{l}\text { Peppermint } \\
\text { flavor }\end{array}$ & Ad libitum & & (Nakamoto, 1979) \\
\hline Salivart & Carboxymethylcellulose & No & Spray & & Ad libitum & & $\begin{array}{l}\text { Epstein \& } \\
\text { Stevenson-Moore, } \\
\text { 1992) }\end{array}$ \\
\hline Moistir & Carboxymethycellulose & No & Spray & & Ad libitum & & $\begin{array}{l}\text { (Epstein \& } \\
\text { Stevenson-Moore, } \\
\text { 1992) }\end{array}$ \\
\hline Polyox & $\begin{array}{l}\text { Polyethylene oxide } 1 \% \\
\text { Water }\end{array}$ & & Glassbottle & Tasteless & Ad libitum & & $\begin{array}{l}\text { (Epstein \& } \\
\text { Stevenson-Moore, } \\
\text { 1992) }\end{array}$ \\
\hline $\begin{array}{l}\text { New oily } \\
\text { formulation }\end{array}$ & $\begin{array}{l}\text { Rice bran oil (RBO Alfa } \\
\left.\text { One }{ }^{\circledR}\right): 30 \% \mathrm{w} / \mathrm{w}\end{array}$ & No & Spray & Flavoring & At least 4 times a day & Distilled water & $\begin{array}{l}\text { (Apperley et al., } \\
\text { 2017) }\end{array}$ \\
\hline
\end{tabular}




\begin{tabular}{|c|c|c|c|c|c|c|c|}
\hline & $\begin{array}{lrr}\begin{array}{l}\text { Soy lecithin } \\
\text { Propylene }\end{array} & \begin{array}{r}\mathrm{w} / \mathrm{w} \\
\text { Water: } 40 \% \mathrm{w} / \mathrm{w}\end{array} \\
\text { glycol }\end{array}$ & & & & & & \\
\hline $\begin{array}{l}\text { OMJ® (Oral } \\
\text { Moisturizing } \\
\text { Jelly) }\end{array}$ & Water-releasing (jelly) & & Gel & $\begin{array}{l}\text { Strawberry } \\
\text { flavour or } \\
\text { lime mint } \\
\text { flavour }\end{array}$ & $10 \mathrm{ml}$ (spoon) 5 times/ day & & $\begin{array}{l}\text { (Dalodom et al., } \\
\text { 2016) }\end{array}$ \\
\hline $\begin{array}{l}\text { New } \\
\text { preparation } \\
\text { saliva } \\
\text { substitute } \\
\end{array}$ & $\begin{array}{l}\text { Distilled water } \\
\text { Methylcellulose } \\
\text { Spirit of chloroform KCl, } \\
\text { NaF, CaCl. }\end{array}$ & & $\begin{array}{l}\text { Mouthwash } \\
5 \mathrm{ml}\end{array}$ & $\begin{array}{l}\text { Essence of } \\
\text { lemon }\end{array}$ & Ad libitum & $\begin{array}{l}\text { Glycerine mouthwash } \\
\text { Distilled water } \\
\text { Spirit of chloroform }\end{array}$ & $\begin{array}{lll}\text { (Klestov } & \text { et } & \text { al., } \\
1981) & & \end{array}$ \\
\hline Aldiamed ${ }^{\circledR}$ gel & Aloe vera gel & & & & Ad libitum & & $\begin{array}{lll}\text { (Momm } & \text { et } & \text { al., } \\
2005) & & \\
\end{array}$ \\
\hline $\begin{array}{l}\text { Glandosane }{ }^{\circledR} \\
\text { spray }\end{array}$ & Carboxymethylcellulose & No & & & Ad libitum & & $\begin{array}{l}\text { (Momm et al., } \\
\text { 2005) }\end{array}$ \\
\hline Rape spray & Rape oil pressed & & Spray & & Ad libitum & & $\begin{array}{l}\text { (Momm et al., } \\
2005)\end{array}$ \\
\hline Margarine & Liquid margarine & & & & Ad libitum & & $\begin{array}{l}\text { (Furumoto et al., } \\
\text { 1998) }\end{array}$ \\
\hline $\begin{array}{l}\text { Saliva Medac }{ }^{\circledR} \\
\text { spray }\end{array}$ & $\begin{array}{l}\text { containing mucin extracted } \\
\text { from pig stomach }\end{array}$ & Yes & Spray & & Ad libitum & & $\begin{array}{l}\text { (Momm et al., } \\
\text { 2005) }\end{array}$ \\
\hline Salivèze ${ }^{\circledR}$ & $\begin{array}{l}\text { aqueous } \\
\text { containing solution calcium } \\
\text { chloride 0.15 mg/mL, } \\
\text { magnesium chloride } 0.05 \\
\mathrm{mg} / \mathrm{mL} \text {, sodium chloride } \\
0.05 \mathrm{mg} / \mathrm{mL} \text {, potassium } \\
\text { chloride } 1.2 \mathrm{mg} / \mathrm{Ml} \text {, sodium } \\
\text { phosphate } 0.28 \mathrm{mg} / \mathrm{mL} \text { and } \\
\text { sorbitol } 30 \mathrm{mg} / \mathrm{mL} \text { in } \\
\text { purified water }\end{array}$ & & Spray & & $\begin{array}{l}\text { At least } 5 \text { times/day } \\
1 \text { or } 2 \text { spray up to } 4 \text { times } \\
\text { a day }\end{array}$ & & $\begin{array}{l}\text { (Mouly, Orler, et } \\
\text { al., 2007; Mouly, } \\
\text { Salom, et al., 2007) }\end{array}$ \\
\hline $\begin{array}{l}\text { New artificial } \\
\text { saliva } \\
\text { formulation }\end{array}$ & $\begin{array}{l}\text { aqueous solution of } \\
\text { potassium thiocyanate, } \\
\text { potassium chloride, sodium } \\
\text { chloride, calcium chloride, } \\
\text { magnesium chloride, } \\
\text { potassium dihydrogen } \\
\text { phosphate, xylitol and citric } \\
\text { acide }\end{array}$ & & Spray & Flavor & At least 2 times / day & & $\begin{array}{l}\text { (Silvestre et al., } \\
\text { 2009) }\end{array}$ \\
\hline
\end{tabular}




\begin{tabular}{|c|c|c|c|c|c|c|c|}
\hline \multirow[t]{2}{*}{ Buccotherm ${ }^{\circledR}$} & \multirow[t]{2}{*}{ Thermal spring water } & & \multirow[t]{2}{*}{ Spray } & & \multicolumn{2}{|l|}{4 times daily } & \multirow{2}{*}{\begin{tabular}{|l}
$\begin{array}{l}\text { (Skrinjar et al., } \\
2015)\end{array}$ \\
(Alpöz et al., 2015)
\end{tabular}} \\
\hline & & & & & 6 times daily & $\begin{array}{l}1 / 10 \text { diluated black } \\
\text { tea(plain water and } \\
\text { Lipton tea) }\end{array}$ & \\
\hline $\operatorname{Xeros}^{\circledR}$ & $\begin{array}{l}\text { Betaine, Sodium fluoride, } \\
\text { Hydroxyethylcellulose }\end{array}$ & No & Mouthwash & & 4 times daily & & $\begin{array}{l}\text { (Skrinjar et al., } \\
\text { 2015) }\end{array}$ \\
\hline $\begin{array}{l}\text { Marshmallow } \\
\text { root }\end{array}$ & $\begin{array}{l}\text { Infusion of marshmallow } \\
\text { root into } 2 \mathrm{dcl} \text { of cold water }\end{array}$ & & Mouthwash & & $\begin{array}{l}\text { Rinsing with one large } \\
\text { spoon } 4 \mathrm{~h} \text { after preparation }\end{array}$ & & $\begin{array}{l}\text { (Skrinjar et al., } \\
\text { 2015) }\end{array}$ \\
\hline Mouth-Kote ${ }^{\circledR}$ & $\begin{array}{l}\text { Yerba santa (Eriodictyon } \\
\text { californicum), Xylitol }\end{array}$ & & Spray & $\begin{array}{l}\text { Lemon } \\
\text { flavor(sorbit } \\
\text { ol/xylitol- } \\
\text { sweetened) }\end{array}$ & Ad libitum & & $\begin{array}{l}\text { (Stewart et al., } \\
\text { 1998) }\end{array}$ \\
\hline \multirow[t]{2}{*}{$\begin{array}{l}\text { TPM } \\
\text { (Traditional } \\
\text { Persian } \\
\text { Medecine) }\end{array}$} & \multirow{2}{*}{$\begin{array}{l}\text { Sachet } 4 \mathrm{~g} \text { of mixed powder } \\
\text { of A. digitata and M. } \\
\text { Sylvestris (in a proportion } \\
\text { of } 1: 1) \text {, in a glass of boiled } \\
\text { water }(250 \mathrm{~mL} \text { ) as one dose. } \\
\text { After } 10 \mathrm{~min} \text {, when the } \\
\text { herbal infusion somewhat } \\
\text { cooled, the patients were to } \\
\text { sip the entire }\end{array}$} & & Sip/Drink & & & & \multirow[t]{2}{*}{$\begin{array}{l}\text { (Heydarirad et al., } \\
\text { 2017) }\end{array}$} \\
\hline & & & Spray & & & $\begin{array}{ll}\text { Hypozalix } & \text { spray } \\
\text { (sodium } & \\
\text { carboxymethyl } & \\
\text { cellulose) } & \end{array}$ & \\
\hline
\end{tabular}

Code de champ modifié 
Table 3: Values of saliva flow rate in the set of seven studies considering saliva flow rate as inclusion criteria

\begin{tabular}{lll}
\hline REFERENCES & Unstimulated saliva method & flow rate \\
\hline (Alpöz et al., 2008) & Spitting method 5 min & $<0.3 \mathrm{~mL} / \mathrm{min}$ \\
(Andersson et al., 1995) & Spitting method 15 min & $<1.5 \mathrm{~mL}$ \\
(Donath et al., 2016) & Swab/test of saliva weight absorbed $5 \mathrm{~min}$ & $\leq 0.5 \mathrm{~g}$ \\
(Furumoto et al., 1998) & Spitting method 5 min & $<0.2 \mathrm{~mL} / \mathrm{min}$ \\
(Mouly, Orler, et al., 2007; & Swab/test of saliva weight absorbed 5 min & $\leq 0.5 \mathrm{~g}$ \\
Mouly, Salom, et al., 2007) & Spitting method & $\leq 0.16 \mathrm{~mL} / \mathrm{min}$ \\
& & \\
\hline & Stimulated saliva method & flow rate \\
\hline (Alpöz et al., 2008) & Drops of acid citric spitting method & $<1 \mathrm{~mL} / \mathrm{min}$ \\
(Alves et al., 2004) & Acid citric on cotton swab 5 min test spitting & $<0.5 \mathrm{~mL} / \mathrm{min}$ \\
(Andersson et al., 1995) & Paraffin chewing 5 min & $<3.5 \mathrm{~mL}$ \\
(Gil-Montoya et al., 2008) & Chewing paraffin 5 min & $\leq 0.7 \mathrm{~mL} / \mathrm{min}$ \\
(Mouly, Orler, et al., 2007; & Chewing paraffin Spitting method & $\leq 0.5 \mathrm{~mL} / \mathrm{min}$ \\
Mouly, Salom, et al., 2007) & & \\
\hline
\end{tabular}

